\title{
PERAN GURU BIMBINGAN DAN KONSELING DALAM MENINGKATKAN HUBUNGAN SEBAYA MENGENAI KEDEWASAAN DI SMK MUHAMMADIYAH 13 SIBOLGA
}

\author{
Asmaryadi \\ Universitas Muhammadiyah Tapanuli Selatan, asmar_yadi@ rocketmail.com
}

\begin{abstract}
Abstrak
Dalam makalah penelitian ini penulis ingin melihat gambaran nyata dari upaya bimbingan dan bimbingan guru dalam meningkatkan hubungan sesama kematangan siswa SMK Muhammadiyah 13 Sibolga 20132014 tahun ajaran. Penelitian ini dilatarbelakangi oleh tingkat perkembangan hubungan persaudaraan yang tidak sesuai dengan perkembangan zaman karena banyak siswa yang menangani masalah yang dihadapi oleh tindakan negatif saat mereka melarikan diri ke hal-hal yang negatif seperti kerusakan yang berlebihan. semua hasil dari kurangnya kedewasaan dalam hubungan rekan siswa. Ada dua variabel dalam penelitian ini, yaitu $\mathrm{x}$ dan, variabel pertama ditujukan untuk mengetahui apakah ada upaya bimbingan dan bimbingan guru (x) hubungan kedewasaan pada siswa sebaya SMK Muhammadiyah 13 Sibolga (y). Objek siswa dan guru SMK Muhammadiyah BK 13 Sibolga menghasilkan data dapat melakukan wawancara dan observasi di lapangan pengamatan pada objek penelitian guru dan rekan siswa. Metode yang digunakan adalah metode penelitian kualitatif deskriptif dalam penelitian kualitatif tidak menggunakan istilah populasi melainkan sebagai kata (Spradley, Sugioyono, 2012: 297) melalui tiga tahap, yaitu situasi, taksonomi, luas wilayah. Karena populasi generalisasi yang terjadi di atas objek dan subjek yang memiliki kualitas tertentu yang ditetapkan oleh peneliti untuk belajar kemudin dapat disimpulkan. Dari penelitian didapatkan hasil kategori "Bagus" analisis data menunjukkan bahwa upaya bimbinganan bimbinganan guru dalam meningkatkan hubungan sesama kedewasaan mencapai nilai yang diharapkan oleh guru BK dalam penelitian ini.
\end{abstract}

Kata kunci: upaya konseling guru dan hubungan sesama kedewasaan

\section{Abstract}

In this research paper the author wishes to see the real picture of the efforts of teacher guidance and counseling in improving peer relationships maturity of students of SMK Muhammadiyah 13 Sibolga 20132014 school year. This research background by the level of development of peer relationships that are not in accordance with the development age because there are many students who are addressing the problems faced by the negative action as they fled into the things that are negative as excessive mischief. all the result of a lack of maturity in students' peer relationships. There are two variables in this study, namely $\mathrm{x}$ and, y first variable is aimed to determine whether there was an attempt teacher guidance and counseling (x) relationship maturity in peer students of SMK Muhammadiyah 13 Sibolga (y). objects were students and teachers of SMK Muhammadiyah BK 13 Sibolga result data can conduct interviews and observations in the field observation on the research object student teachers and peers. The method used is descriptive qualitative research methods in qualitative research does not use the term population but as word (Spradley, in Sugioyono, 2012: 297) through three stages, namely the situation, taxonomy, area. Because the population of generalization that occurs over the object and subject that has certain qualities that set by the researcher to learn kemudin be deduced. of research gets results category "Good" data analysis showed that the teachers bimbinganan counseling efforts in improving peer relationships maturity reached the expected value by BK teachers in this study.

Keywords : efforts counseling teacher and peer relationships maturity

\section{PENDAHULUAN}

Masa peralihan atau masa transisi atau yang lebih dikenal dengan masa pubertas akan dialami oleh anakanak, sering kali menjadi permasalahan bagi anak-anak. Perubahan bentuk fisiologis yang menendai pubertas tidak jarang membuat anak-anak yang mengalami fase transisi ini kebingungan dan takut. Mulai akan ketakutan akan perubahan bentuk tubuh sampai takut membangun hubungan dengan teman sebaya. Adapun Pubertas adalah periode dalam rentang perkembangan ketika anak-anak berubah dari mahluk aseksual menjadi mahluk seksual.
Seperti diterangkanoleh Root,dalam Tim Dosen (1998:23)"Masa puber adalah suatu tahap dalam perkembangan dimana terjadi kematangan alat-alat seksual dan tercapai kemampuan reproduksi. Tahap ini disertai dengan perubahan-perubahan dalam pertumbuhan somatis dan perspektif psikologis". Salah satu tuga perkembangan yang harus dilaksanakan atau dialami oleh remaja adalah membangun relationship atau membangun hubungan terutama dengan teman sebaya. Sebelum memasuki masa remaja, anak-anak menghabiskan waktu lebih banyak dengan orang dewasa. banyak upaya yang harus dilakukan agar tercipta 
kematangan dalam diri teman sebaya tersebut hal ini sesuai dengan tujuan (Tim Departemen Nasional, 2003:11) yaitu "untuk mengembangkan potensi anak didik agar menjadi manusia yang beriman dan bertaqwa kepada Tuhan yang Maha Esa, berakhlak mulia, cakap, kreatif, mandiri, dan menjadi warga Negara yang demokratis serta bertanggung jawab".

Moral dan religi merupakan bagian yang cukup penting dalam jiwa teman sebaya.sebagian orang berpendapat bahwa moral dan religi bisa mengendalikan tingkahlaku anak yang beranjak dewasa ini sehingga ia tidak melakukan hal-hal yang merugikan atau bertentangan dengan kehendak atau pandangan masyarakat.

Disisi lain tiadanya moral dan religi ini seringkali dituding sebagai factor penyebabkan kematangan dalam hubungan teman sebaya. Dalam hal ini agama mengatur tingkahlaku baik buruk, secara psikologis termasuk dalam moral. Hal lain yang termasuk dalam moral adalah sopan santun, tata krama, dan norma-orma masyarakat lainnya. Sesuai dengan konsep (Sigmund Freud dalam SarlitoW.Sarwono, 2012:109) "Agama adalah bagian dari jiwa yang berfungsi untuk mengendalikan tingkah laku". Seperti yang diterangkan oleh (Nikerson dalam Nagle, 2005:240) "Kelompok yang pertama sekali berperan penting sebagai kelompok rujukannya adalah keluarga, maka keluarga memberikan ciri-ciri dasar kepribadian seseorang dan kelompok yang kedua yaitu pihak sekolah, khususnya guru, yang menjadi kelompok rujukan berikutnya bagi peserta didik dan kemudian kelompok berikutnya yaitu teman sebaya (peer group) dalam mengembangkan sikap dan perilaku maka kelompok teman sebaya bersifat informal dan langsungmenunjukkan bahwa masa remajakedekatan hubungan dengan teman sebaya meningkat secara drastis, dan pada saat yang bersamaan kedekatan hubungan remaja dengan orangtua menurun secara drastis".

\section{Identifikasi Masalah}

Sesuai dengan latar belakang masalah,maka perlu adanya identifikasi masalah yaitu:

a. Dalam hubunganteman sebaya tersebut kurang interaksi dengan kelompok teman sebaya lainnya.

b. Dalam keseharian teman sebaya Kurang rasa kerja sama (team work) baik dalam perlombaan maupun bersifat individu.

c. Adanya upaya guru bimbingan dan konseling dalam meningkatkan kematanganhubungan teman sebaya.

\section{Batasan Masalah}

Agar pokok bahasan ini tidak meluas dan terarah, maka penelitian ini dibatasi pada Upaya-upaya yang dilakukan oleh guru bimbingan dan konseling dalam meningkatkankematangan hubungan teman sebaya siswa di SMK Muhammadiyah 13 Sibolga.

\section{Perumusan Masalah}

Dari latarbelakang diatas, maka penulis dapat merumuskan masalah dalam penelitian ini yaitu ;

a. Bagaimana upaya guru bimbingan dan konseling dalam meningkatkan kematangan hubungan teman sebaya siswa SMK Muhammadiyah 13 Sibolga?

b. Bagaimanakah penyelenggaraan upaya guru bimbingan dan konseling dalam meningkatkan kematangan hubungan teman sebayasiswa SMK Muhammadiyah 13 Sibolga?

c. Bagaimanakah hasil dari upaya guru bimbingan dan konseling dalam meningkatkan kematangan hubungan teman sebaya siswa SMK Muhammadiyah 13 Sibolga?

\section{Tujuan Penelitian}

Penelitian ini bertujuan untuk mengetahui penerapan fungsi bimbingan dan konseling untuk meningkatkan kematangan hubungan siswa dengan teman sebaya sedangkan secara mendalam tujuan penelitian ini yaitu untuk mengetahui bagaimana upaya guru pembimbing dalam mengatasi permasalahan hubungan teman sebaya tersebut.

\section{METODOLOGI}

Penelitian ini bersifat kualitatif karena berlandaskan teoriteori, Format desain penelitian kualitatif secara teoritis berbeda dengan format penelitian kuantitatif, namun perbedaannya terletak pada kesulitan didalam membuat desain penelitian kualitatif itu sendiri karena pada umumnya pembuatan penelitian kualitatif yang tidak berpola, kesulitan membuat desain penelitian kualitatif disebabkan karena :

a. Desain penelitian kualitatif itu adalah penelitian sendiri, sehingga peneliti yang paham pola penelitian yang akan dilakukan.

b. Ragam ilmu sosial yang variannya bermacammacamformatdeskriftif, format verifikatif, dan format grounded theory.

Berdasarkan pengalaman dalam melakukan berbagai penelitian kualitatif, seperti diterangkan seorang ahli Glaser dan Strauss dalam BurhanBungin, 2007:72) bahwa"penelitian kualitatif ini termasuk dalam jenis penelitian grounded theory yang diperkenalkan pada ilmu pendidikan diseluruh penjuru dunia yang bertujuan untuk pengelompokan jenis penelitian induktif dan berfaradigmafenomenologis dan tertutup pada teori awal penelitian".

\section{a. Informan Penelitian}

Informan merupakan orang yang dimanfaatkan untuk memberikan informasi tentang situasi dan kondisi latar penelitian.dalam penelitian kualitatif tidak menggunakan istilah populasi, tetapi oleh (Spradley, 297:2012) dinamakan "sosial situasition" atau sistuasi sosial yang terdiri atas tiga elemen yaitu tempat, pelaku, aktivitas, yang berinteraksi secara sinergis situasi sosial tersebutdapatdirumah berikut keluarga dan aktivitas dalam menentukan siapa yang akan dijadikan informan penelitian, peneliti lebih dulu menentukan informan kunci dan selanjutnya dari informan kunci ditetapkan informan selanjutnya.

1. Dalam penelitian ini sebagai informan kunci yaitu guru BK SMK Muhammadiyah 13 Sibolga, dan siswa Penentuan informan lanjutan dilakukan melalui teknik Snowball sampling. 
Penentuan informan lanjutan dijajaki melalui petunjuk dan saran dari informan kunci yaitu: guru dan siswa. Jumlah informan disesuaikan dengan kebutuhan data yang diperlukan. Apabila data yang dikemukakan bukan suatu data yang baru dan cenderung mengulang apa yang diungkap informan sebelumnya maka pengumpulan data dianggap cukup.

2. Terdapat perbedaan yang mendasar dalam pengertian antara pengertian "populasi dan sampel" dalam penelitian kuantitatif dan kualitatif dalam penelitian kuantitatif, populasi diartikan sebagai daerah generalisasi yang terdiri atas objek dan subjek yang memiliki kualitas dan karakteristik tertentu yang ditetapkan oleh peneliti untuk diteliti dan ditarik kesimpulannya.

3. Dalam penelitian kualitatif tidak menggunakan istilah populasi tetapi seperti kata (Spradley, dalam Sugiyono, 2012:297) dinamakan "social situation atau situasi sosial yang terdiri dari tiga elemen tempat,pelaku,dan aktivitas yang berinteraksi secara sinergis.Populasi adalah keseluruhan objek yang akan diteliti, populasi sangat penting dilakukan dalam melakukan suatu penelitian karena populasi merupakan variabel yang diperlukan dalam melakukan analisis data.

\section{b. Teknik Pengumpulan Data}

Untuk mendapatkan dan menghimpun data dilapangan penulis menggunakan beberapa teknik pengumpulan data yaitu:

a. Observasi/pengamatan langsung

peneliti terjun langsung kelapangan untuk melihat fakta-fakta yang akan diteliti.Dalam hal ini penelitian difokuskan di SMK Muhammadiyah 13 Sibolga dengan objek pengamatan adalah siswa dan guru bimbingan dan konseling.

b. Wawancara/interview

Peneliti bisa kontak langsung dengan responden, sehingga dapat mengungkap jawaban secara lebih bebas dan mendalam untuk pertanyaan yang lebih jelas dan dapat diulang dan dijelaskan oleh peneliti". Sebaiknya jawaban yang belum jelas biasa diminta lagi lebih terarah dan lebih bermakna, asal pewawancara tidak mempengaruhi atau mengarahkan pendapat responden. Ada dua jenis wawancara yakni : II C DICOS JW

c. Dokumentasi

Disamping metode wawancara dan observasi sebagai metode utama, penulis juga menggunakan metode dokumentasi pada penelitian ini.Dokumentasi merupakan metode yang digunakan dalam mengumpulkan datang dibutuhkan dalam penelitian.Dokumentasi dalam penelitian ini adalah buku, majalah artikel dan lain sebagainya.Yang berkenaan dengan upaya guru bimbingan dan konseling dalam meningkatkan kematangan hubungan teman sebaya.

\section{c. Teknik Analisis Data}

Teknik analisis data dilakukan sebelum memasuki lapangan, selama dilapangandan setelah selesai penelitian dilapangan. Dan kata lain analisa berlangsung selama proses pengumpulan data dari awal sampai proses pengumpulan data selesai.

Teknik analisis data yang digunakan didalam penelitian ini yaitu :

\section{Data reduction}

Data yang diperoleh dari lapangan cukup banyak untuk itu perlu dicatat secara teliti dan rinci.Teknik ini dilakukan dengan merangkum, memilih hal yang pokok, dicari tema dan polanya. Dengan demikian akan memberikan gambaran yang lebih jelas dan mempermudah peneliti melakukan pengumpulan data selanjutnya.

2. Data display (penyajian data)

Mendisplaykan data atau menyajikan data dalam bentuk uraian singkat,bagan hubungan kategori dan sejenisnya, dengan mendisplaykan data dapat mempermudah untuk memahami apa yang terjadi, merencanakan kerja selanjutnya berdasarkan apa yang telah dipahami tersebut.

3. Conclusion drawing verivication

Teknik ini adalah teknik terakhir dalam penelitian ini yaitu dengan cara menarik kesimpulan dan verivikasi. Kesimpulan awal yang dikemukakan masih bersifat sementara, dan akan berubah bila tidak ditemukan bukti kesimpulan yang dikemukakan pada tahap awal, didukung oleh bukti yang valid dan konsisten saat peneliti kembali kelapangan mengumpulkan data, maka kesimpulan yang dipercaya".

HASIL

\section{Temuan umum}

A. Gambaran umum Kota Sibolga

Kota Sibolga adalah salah satukota di Provinsi Sumatera Utara yang terletak di Indonesia. Kota ini terletak di pantai barat pulau Sumatera, membujur sepanjang pantai dari utara ke selatan dan berada pada kawasan teluk yang bernama Teluk Tapian Nauli, sekitar $\pm 350 \mathrm{~km}$ dari kota Medan. Kota ini hanya memiliki luas $\pm 10,77 \mathrm{~km}^{2}$ dan berpenduduk sekitar 84.481 jiwa. Pada masa Hindia-Belanda kota ini pernah menjadi ibu kota Residentie Tapanuli Setelah masa kemerdekaan hingga tahun 1998, Sibolga menjadi ibu kotatapanuli tengah. Kota Sibolga dipengaruhi oleh letaknya yaitu berada pada daratan pantai, lereng, dan pegunungan. Terletak pada ketinggian berkisar antara $0-150$ meter dari atas permukaan laut, dengan kemiringan lahan kawasan kota ini bervariasi antara 0-2 \% sampai lebih dari $40 \%$.

Iklim kota Sibolga termasuk cukup panas dengan suhu maksimum mencapai $32^{\circ} \mathrm{C}$ dan minimum $21.6^{\circ} \mathrm{C}$. Sementara curah hujan di Sibolga cenderung tidak teratur di sepanjang tahunnya. Curah hujan tertinggi terjadi pada bulan November dengan jumlah $798 \mathrm{~mm}$, sedang hujan terbanyak terjadi pada Desember yakni 26 hari. Pulaupulau yang termasuk dalam kawasan kota Sibolga adalah Pulau Poncan Gadang, Pulau Poncan Ketek, Pulau Sarudik dan Pulau Panjang.

Dengan batas-batas wilayah: timur, selatan, utara pada Kabupaten Tapanuli Tengah, dan barat dengan Samudera Hindia. Sementara sungai-sungai yang mengalir di kota tersebut adalah Aek Doras, Sihopo-hopo, 
Aek Muara Baiyon, dan Aek HorsikMasyarakat Sibolga terdiri dari bermacam-macam etnis, antara lain Batak Toba, Batak Mandailing, dan Minangkabau. Namun dalam kesehariannya, bahasa yang dipergunakan adalah bahasa minangkabau logat Pesisir.Potensi utama perekonomian bersumber dari perikanan, pariwisata, jasa, perdagangan dan industri maritim. Hasil utama perikanan, antara lain, kerapu, tuna, kakap, kembung, bambangan, layang, sardines, lencam dan teri. Berikut gambar lambang kota Sibolga dan Kota pelabuhan di Kota Sibolga.

B. Gambaran umum SMK Muhammadiyah 13 Sibolga

1. SMK Muhammadiyah 13 Sibolga adalah salah satu lembaga pendidikan yang ada di Tapanuli Tengah, sekolah tersebut beralamat di JL.DE.Sutan Bungaran Panggabean No.20. Kecamatan Sibolga Selatan kota sibolga. Sekolah ini didirikan pada tanggal 1 Desember 1997 dan merupakan sekolah Swasta yang dikelola oleh Majlis Dikdasmen PDM Kota Sibolga. SMK Muhammadiyah 13 mempunyai tiga jurusan diantaranya jurusan akutansi, jurusan administrasi, jurusan teknik komputer dan jaringan adapun jumlah siswa belajar terdiri dari 331 siswa.

2. Gambaran rinci kondisi guru SMK Muhammadiyah 13 Sibolga terlihat pada tabel dibawah ini:

Tabel 1

Rincian guru SMK Muhammadiyah 13 Sibolga

\begin{tabular}{|c|c|c|c|c|}
\hline \multirow{2}{*}{ No. } & \multirow{2}{*}{ Mata Pelajaran } & \multirow{2}{*}{ Kebutuhan } & \multicolumn{2}{|c|}{ Yang ada } \\
\hline & & & GT & GTT \\
\hline (1) & (2) & (3) & (4) & (5) \\
\hline 1 & PPKn & 2 & 2 & \\
\hline \multirow[t]{6}{*}{2} & Pendidikan Agama & & & \\
\hline & a. Islam & 3 & 1 & 1 \\
\hline & b. Protestan & & & \\
\hline & c. Katolik & & & \\
\hline & e. Budha & & & \\
\hline & f. Konghuchu & & & \\
\hline 3 & $\begin{array}{l}\text { Bhs. dan Sastra } \\
\text { Indonesia }\end{array}$ & 2 & 2 & 2 \\
\hline 4 & Bahasa Inggris & 2 & 2 & \\
\hline \multicolumn{5}{|l|}{5} \\
\hline 6 & Pendidikan Jasmani & 2 & 1 & \\
\hline 7 & Matematika & 2 & 2 & \\
\hline \multirow{4}{*}{8} & Produktif akutansi & 5 & 2 & \\
\hline & $\begin{array}{ll}\text { A. } & \text { Produktif } \\
\text { ADM } & \\
\end{array}$ & 4 & 2 & \\
\hline & $\begin{array}{l}\text { C. } \\
\text { Tata Negara }\end{array}$ & & & \\
\hline & $\begin{array}{l}\text { D. } \\
\text { Antropologi }\end{array}$ & & & \\
\hline 9 & $\begin{array}{l}\text { Tehnologi Informatika } \\
\text { Komputer }\end{array}$ & 4 & 3 & \\
\hline
\end{tabular}

\begin{tabular}{|c|l|c|c|c|}
\cline { 2 - 5 } $\mathbf{1 0}$ & Pendidikan Seni & 2 & 1 & \\
\hline $\mathbf{1 1}$ & Bahasa Asing Lain & 2 & 2 & \\
\hline $\mathbf{1 3}$ & $\begin{array}{l}\text { Bimbingan dan } \\
\text { Konseling }\end{array}$ & 1 & 1 & \\
\hline $\mathbf{1 4}$ & $\begin{array}{l}\text { Muatan Lokal } \\
\text { Kerajinan Tangan dan } \\
\text { Kesenian }\end{array}$ & & & 1 \\
\hline $\mathbf{1 5}$ & Kewirausahaan & & & \\
\hline $\begin{array}{l}\text { Jumlah } \\
\text {......................................................... } \\
\text {.. }\end{array}$ & & 22 & 4 \\
\hline
\end{tabular}

Sumber: Dok.SMK Muhammadiyah 13 Sibolga

\section{Temuan Khusus Penelitian}

\section{A. Profil informan}

Sebelum mengetahui gambaran tentang hubungan kematangan teman sebaya dan kerja sama guru BK untuk mengatasinya maka akan diberikan gambaran secara umum profil masing-masing informan.

B. Gambaran upaya guru bimbingan dan konseling dalam Meningkatkan Kematangan Hubungan Teman Sebaya

Setelah mengumpulkan data yang terkait dengan fokus penelitian,maka dapat diperoleh gambaran tentang masalah kematangan hubungan teman sebaya secara rinci gambaran hubungan kematangan teman dalam lingkungan siswa adapun gejala-gejala yang muncul dalam pertumbuhan terhadap tingkahlaku teman sebaya menurut (Tim Dosen, 1998:40) sebagai berikut:

1. Keinginan untuk menyendiri

Hal ini terjadi karena anak tidak ada perhatian lagi pada teman-temannya. Dia mengasingkan diridari kelompoknya dan lebih senang duduk sendirian, tapi jika dilingkungan rumah ia hanya akan dikamarnya dengan pintu tertutup.

2. Keseganan untuk bekerja

Anak pada masa kanak-kanak selalu sibuk dan nampaknya tidak pernah capek bekerja atau bermain-main, sekarang selalu capek. Akibatnya adalah bahwa dia bekerja sedikit mungkin. Kewajiban-kewajiban dirumah seringkali tidak dijalankan lagi dan pelajaran-pelajaran di sekolah seringkali tidak dihiraukan. Sebenarnya untuk bekerja ini bukanlah disebabkan karena kemalasan atau karena adanya perubahan dalam tingkat inteleknya, akan tetapi ternyata bahwa hal itu adalah akibat dari perkembangan jasmaniah yang berjalan dengan cepat, sehingga ia membutuhkan banyak energi dari badannya.

3. Merasa bosan

Anak pada masa pubertas merasa bosan dengan permainan yang dahulu disenanginya, dengan pekerjaan sekolahnya dan dengan menunjukkan rasa bosannya dengan jalan menolak untuk menjalankan keaktifan-keaktifan yang dulu dikerjakannya dengan senang hati.

4. Berrsikap tidak tenang

Bagi anak kecil hal-hal yang menarik perhatiannya adalah bemain dengan apa yang ada di sekitarnya, 
akan tetapi dalam kehidupan remaja yang bergabung dalam kelompok teman sebaya hal seperti itu sekarang tidak lagi. Oleh karena itu dia mencobacoba bermacam-macam hal yang dapat dikerjakannya dengan senang hati dan yangmemuaskannya. Suatu sebab yang lain dari pada sikap tidak tenang pada kelompok teman sebaya adalah sebab yang bersikap fisik.

5. Antagonisme social

Anak puber mempunyai kebiasaan untuk menunjukkan sikap kehendak orang lain. Dia memberikan kesan, bahwa dia selalu ingin meniadakan kesenangan-kesenangan orang lain, dengan jalan tidak mau diajak membuat persetujuan, tidak mau bekerja sama dan sependapat mungkin menentang kehendak-kehendak pihak lain.

6. Menentang orang lain yang lebih berkuasa dari padanya

Dalam masa ini seringkali terlihat adanya konflikkonflik antara anak-anak puber atau kelompoktemansebaya dengan orang tuanya, terutama dengan ibunya, oleh karena dia lebih banyak berhubungan dengan ibu. Anak pada umur ini tidak mau dikuasai dan dia berusaha sekuatnya untuk menentang orang yang dikiranya akan menguasai dia. Biasanya, anak pada masa pubertas ini tidak berbuat demikian jahat, sehingga dia dapat dikatakan "anak nakal", akan tetapi dia memang gemar membuat heboh dan seringkali dikuasai oleh keinginnanya untuk buat orang jengkel.

7. Antagonis seks

Permusuhan-permusuhan yang terang-terangan seringkali nampak pada masa ini antara anak-anak pria dan wanita. Biasanya anak wanita mununjukkan rasa permusuhan yang lebih mendalam terhadap anak pria dari pada sebaliknya. Apabila dalam masa kanak-kanak rasa permusuhan ini ditunjukkan pada dengan jalan saling menghindari antara anak- anak wanita dan pria, sekarang terdapat permusuhan yang terbuka, dimana anak-anak itu saling mengolok-olok dan menghina.

8. Emosionalita

Anak dalam masa pubertas sering kali merasa marah-marah dan merasa sedih dan ingin menangis karena sebab-sebab yang kecil saja.hal-hal ini adalah keadaan-keadaan emosional yang khas bagi anak puber.lagi pula,segala sesuatu yang dikatakan oleh orang lain mengenai diri mereka kepada mereka mudah sekali dianggap sebagai kecaman.perasaan mereka senantiasa tersinggung dan seringkali mereka merasa dihina.biasanya anak puber lekas marah dan senang bertengkar dengan saudarasaudaranya.

C. Guru Bimbingan dan Konseling dalam meningkatkan kematangan hubungan kematangan teman sebaya

Latar Belakang Perlunya menngkatkan kematangan hubungan teman sebaya berdasarkan penelitian diperoleh bahwa terdapat beberapa hal yang menjadi latar belakang adanya upaya guru bimbingan dan konseling dalam meningkatkan kematangan hubungan teman sebaya.Seperti yang dijelaskan oleh guru BK SMK Muhammadiyah 13 Kota Sibolga mengatakan bahwa:

"kebanyakan kelompok teman sebaya menolak untuk ikut dalam suatu kegiatan sekolah, alasannya adalah bosan dengan kegiatan yang itu saja dari tahun ketahun, dan mereka merasa itu sudah membosankan sepeti yang kita tahu dalam masa perkembangan yang ada pada diri mereka sekarang ini mereka membutuhkan sesuatu hal baru yang tak membuat mereka merasa bosan, setiap orde kegiatan umpanya bisa ditukar dengan kegiatan yang belum pernah diadakan ".

(Wawancara tanggal 20 0ktober 2014 pada pukul 12:00)

Dari penjelasan guru BK sudah terlihat bahwa kelompok teman sebaya belum bisa mengendalikan dirinyanya untuk bisa menciptakan suasana baru itu dari dalam dirinya sendiri seperti yang dikatakan seorang informan saat diwawancarai bahwa:

"saya sangat mudah bosan dengan guru tertentu yang hanya bisa menerangkan dengan suara keras dan kemudian memberikan tugas yang bertubi-tubi,akan tetapi tidak semua guru monoton, sebagian ada yang mampu membuat saya betah dikelas dan belajar mata pelajarannya."

(Wawancara tanggal 21 oktober 2014 pukul 09:30)

\section{PEMBAHASAN}

Gambaran upaya guru bimbingan dan konseling dalam meningkatkan kematangan hubungan teman sebaya yang dilakukan oleh siswa dilakukan ketika siswa memiliki keinginan yang tinggi terhadap sesuatu, yaitu kebebasan dalam bertindak.keinginan tersebut tidak diperoleh.faktor utama yang menjadi penyebab siswa tidak matang adalah faktor lingkungan.

Sikap tidak matang sering terjadi di ruang kelas pada saat proses pembelajaran berlangsung. Ketika siswa merasa bosan dan jenuh, maka siswa menjadikan saat itu untuk berkelakuan buruk sebagai pelarian. Perilaku tersebut selain disebabkan oleh pengaruh dari teman Dalam lingkungan tersebut, siswa akan menjadi tertekan ketika tidak mengikuti arus yang terbentuk dalam pergaulan dengan temannya tersebut.

Komunitas siswa yang diteliti memberikan gambaran bahwa siswa remaja tidak dapat pembelajaran tentang perkembangan diri remaja, Siswa akan diterima dalam kelompok ketika mereka mengikuti ajakan sebagaian besaraktifitas yang diikuti oleh anggota kelompok.

Bagi anggota kelompok yang tidak mengikuti maka akan mendapatkan tekanan ( peer pressure). Hunt dan horton (1993) menyatakan bahwa masa remaja merupakan masa pembentukan kelompok teman sebaya yang disebut dengan peer groups.

Pembahasan temuan penelitian terkait dengan upayaguru BK dengan orangtua siswa dalam meningkatkan kematangan hubungan teman sebaya secara rinci akan dilakukan sebagai berikut:

Gambaran perilaku tersebutdilakukan ketika siswa memiliki keinginan yang tinggi terhadap sesuatu, yaitu tentang seksualitas. Rasa keingintahuan tersebut tidak 
diperoleh dari orangtua siswa dan diperoleh dari temannya.

\section{KESIMPULAN}

Berdasarkan hasil penelitian tentang upaya guru bimbingan dan konseling dalam meningkatkan kematangan hubungan teman sebaya siswa untukmeningkatkannya di SMK Muhammadiyah 13 Sibolga, maka dapat diambil kesimpulan sebagai berikut:

1. Bimbingan dan konseling dalam meningkatkan kematangan teman sebaya

Tingkat kematangan hubungan teman sebaya oleh siswa SMK Muhammadiyah 13 sibolga masih sangat rendah dan butuh proses pembelajaran baik secara internal maupun eksternal. Pada proses pembelajaran mereka masih saja menentang perintah guru apabila ada tugas individu maupun kelompok, membuat keributan hingga menggangu proses belajar.Perilaku kurangnya kematangan dalam berhubungan ini disebabkan karena mereka masih dalam masa perkembangan dan hal ini akan dilalui oleh remaja manapun hanya saja kontrol sosial yang tidak mendukung berdampak negative pada kepribadian kelompok teman sebaya . seperti halnya tentang masalah seksualitas, namun guru atau orangtua kurang peka terhadap keinginan tersebut, sehingga mereka mencari informasi kepada orang lain, apabila siswa tersebut terlebih dulu diberi pendidikan seks kemungkinan dia akan matang dalam memahami makna dan fungsi seks hingga terhindar dari salah satu aspek buruk yaitu antagonisme seks.

2. Kendala-Kendala yang Dihadapi Guru BK dalam meningkatkan kematangan hubungan teman sebaya

Upaya yang dilakukan oleh guru BK dalam meningkatkan kematangan hubungan teman sebaya siswa merupakan langkah strategis yang dapat meningkatkan efektiftas upaya tersebut.Namun, dalam realitanya upaya yang dilakukan guru BK mengalami kendala-kendala. Kendala-kendala yang dihadapi oleh guru BKdalam meningkatkan kematangan hubungan teman sebaya siswa.

a) Siswa sering malas untuk datang keruang BK atau ke sekolah.

b) siswa beranggapan bahwa masalah tersebut adalah wajar siswa tidak merasa malu dan kurang terbuka jika menceritakan atau memberikan informasi kepada guru BK tentang kondisinya.

\section{SARAN}

Berdasarkan hasil penelitian upaya guru BK dalam meningkatkan kematangan hubungan teman sebaya terdapat beberapa hal yang dapat dijadikan sebagai saran kepada pihak-pihak yang terkait . Saran-saran yang dapat diberikan adalah sebagai berikut :

Menjalin kerjasama dalam meningkatkan kematangan hubungan temansebaya merupakan kegiatan yang memiliki banyak manfaat dalammembentuk karakter anak. Oleh karena itu, hendaknya kepala sekolah dapatmemberikan dukungan kepada guru Bk dalam melaksanakan kegiatantersebut, baik secara moral ataupun spiritual.

Berdasarkan hasil penelitian, salah satu factor kurangnya kematangan hubungan teman sebaya siswa adalah merasa bosan dengan cara mengajar guru. Oleh karena itu, disarankan kepada guru mata pelajaran bisa memahami karaktersitik siswa dalam belajar, sehingga bisa melaksanakan proses pembelajaran yang menarik dan juga disarankan kepada guru mata pelajaran untuk dapat memotivasi siswa dengan memberikan penguatan kepada siswa.

Orangtua adalah pihak yang memiliki peran yang sangat besar dalam membantu meningkatkan kematangan hubungan teman sebaya siswa oleh karena itu, diharapkan orangtua mau terbuka dalam memberikan informasi, meluangkan waktu untuk berkordinasi dengan guru Bk, dan semakin memperhatikan perkembangan mental anak dan memberikan perhatian yang lebih terhadap setiap perubahan-perubahan yang terjadi pada anak.

Sebelum dilakukan penelitian, maka terlebih dahulu peneliti mempersiapkan alat bantu yang digunakan dalam hal ini alat bantu yang digunakan adalah kematangan hubungan teman sebaya melalui wawancara kematangan hubungan teman sebaya dalam penelitian ini disusun berdasarkan indikator.

\section{DAFTAR PUSTAKA}

Glaser dan Strauss .,2007.Penelitian Kualitataif, Jakarta: Kencana Prenada Media Group.

Hurton dan Hunt dalam Damsar.,2011.Pengantar Sosiologi Pendidikan, Jakarta: Prenada Media Group.

Nikerson dalam Nagle.,2003.Psikolgi Remaja, Jakarta:

Root dalam Tim Dosen ,2007.Perkembangan Peserta Didik, Medan: Diktat Institute K egururan.

Sigmund. F. dalam Sarlito W. Sarwono ,Psikologi Remaja, Jakarta: PT Raja Grafindo, 2012

Spradley dalam Sugiyono.,2012.Metode Penelitian Kuantitatif, Kualitatif Kombinasi , Bandung: Alfabeta.

W.G Summer D alam Sarlito , W. Sarwono.,2012. Psikologi Remaja, Jakarta: PT Raja Grafindo Persada. 